\title{
PENGARUH SENAM AEROBIK INTENSITAS SEDANG DAN TINGGI TERHADAP TEKANAN INTRAOKULER WANITA DEWASA NON GLAUKOMA
}

\author{
${ }^{1}$ Jimmy F. Rumampuk \\ ${ }^{1}$ Wenny Supit \\ ${ }^{2}$ Djon Wongkar
}

\author{
${ }^{1}$ Bagian Fisika Fakultas Kedokteran Universitas Sam Ratulangi Manado \\ ${ }^{2}$ Bagian Anatomi-Histologi Fakultas Kedokteran Universitas Sam Ratulangi Manado \\ Email: jimmyfrumampuk@yahoo.com
}

\begin{abstract}
The influence of aerobic fitness to certain physiologic changes of the body, in this case a decrease of intraocular pressure (IOP), has not been elucidated yet. This study aimed to examplify the influence of medium and high intensity aerobic fitness to the IOPs of non-glaucomatous adult females by involving 30 subjects $(n=30)$ in accordance with the inclusion criteria. Prior to doing the aerobic fitness, body weight $(\mathrm{BW})$, height $(\mathrm{H})$, body mass index (BMI), and the arterial pulse were measured. The IOPs were measured by using a Schiotz Tonometer. Aerobic fitness was conducted under the supervision of a fitness instructor. Subjects in the treatment group carried out aerobic fitness on a regular basis. A mild intensity aerobic fitness was carried out for 30 minutes and a high intensity one for 15 minutes. There was a significant difference between the IOP values of postaerobic fitness in the mild intensity group and the high intensity group $(P<0.05)$. This is shown by the average IOP value of post-aerobic fitness in the mild intensity group $15.37 \pm 1.261 \mathrm{mmHg}$, and the average IOP value of post-aerobic fitness in the high intensity group decreasing to $12.92 \pm 1.111$ mmHg. Conclusion: aerobic fitness can decrease the IOP.
\end{abstract}

Keywords: intra-ocular, aerobic fitness, female, non-glaucomatous

\begin{abstract}
Abstrak: Pengaruh senam aerobik dalam mengakibatkan perubahan fisiologik tubuh berupa penurunan tekanan intraokuler (TIO) belum jelas diketahui. Penelitian ini bertujuan untuk mengetahui pengaruh senam aerobik intensitas sedang dan tinggi terhadap TIO wanita dewasa nonglaukoma dengan mengikutsertakan 30 subyek $(n=30)$ yang sesuai dengan kriteria inklusi. Sebelum melakukan senam aerobik, dilakukan pengukuran berat badan (BB), tinggi badan (TB), Indeks Massa Tubuh (IMT), serta denyut nadi. TIO diukur dengan menggunakan Tonometer Schiotz. Kegiatan senam aerobik dibimbing oleh seorang instruktur senam. Kelompok perlakuan melaksanakan aktifitas senam aerobik secara berkesinambungan. Senam aerobik intensitas sedang dilakukan selama 30 menit dan senam aerobik intensitas tinggi dilakukan selama 15 menit. Terdapat perbedaan nilai TIO yang bermakna sesudah senam aerobik intensitas sedang dengan sesudah senam aerobik intensitas tinggi $(P<0,05)$. Hal ini terlihat pada hasil rerata TIO pada kelompok perlakukan sesudah senam aerobik intensitas sedang sebesar 15,37 $\pm 1,261 \mathrm{mmHg}$ dan sesudah senam aerobik intensitas tinggi menurun menjadi 12,92 $\pm 1,111$. Simpulan: senam aerobik dapat menurunkan TIO.
\end{abstract}

Kata kunci: intraokuler, senam aerobik, wanita, non-glaukoma

Glaukoma adalah suatu keadaan di mana terjadi kenaikan tekanan intraokuler (TIO) yang menyebabkan kerusakan/kelainan pada diskus optikus dan lapangan pandang. ${ }^{1}$ Glaukoma merupakan penyakit mata yang penting karena di samping sebagai penyebab kebutaan tertinggi nomor dua di Indonesia setelah katarak, penyakit ini juga dapat menimbulkan kelainan yang bersifat permanen. $^{2}$ 
Penanganan kasus glaukoma ditujukan pada usaha untuk menurunkan TIO, yaitu dengan pemberian obat-obatan. Teoritis, TIO dapat diturunkan dengan penurunan $\mathrm{pH}$ darah dan peningkatan tekanan karbondioksida di dalam darah. ${ }^{3}$ Salah satu penentu TIO ialah pembentukan cairan akueus yang berasal dari sekresi aktif ion natrium, kalium, bikarbonat, serta ion lainnya dari epitel badan siliar. Pada manusia telah dibuktikan penurunan jumlah produksi cairan akueus sekitar $50 \%$ disebabkan asidosis sistemik. ${ }^{4}$

Di Indonesia, Junaidi (1999) ${ }^{5}$ meneliti pengaruh latihan beban terhadap TIO pada orang normal yang melakukan kontraksi isometrik dengan menggunakan alat dinamometer dorong (push dynamometer). Hasil penelitian menunjukkan bahwa setelah 30 menit kemudian didapatkan penurunan TIO sebesar $3 \mathrm{mmHg}$. Penelitian-penelitian terdahulu tidak pernah melaporkan adanya peningkatan TIO pada penderita glaukoma yang melakukan olah raga. Berdasar hasil tersebut dapat disimpulkan bahwa latihan olah raga aman untuk mata penderita glaukoma. Penurunan TIO yang didapat dengan olah raga terbatas, sehingga olah raga hanya dapat dimanfaatkan sebagai terapi tambahan untuk menurunkan TIO. ${ }^{5}$

Sampai saat ini belum ada peneliti yang menelusuri pengaruh senam aerobik terhadap TIO. Mengingat olahraga senam aerobik banyak dilakukan oleh masyarakat luas dengan rentang usia muda sampai tua, maka hal ini menarik minat peneliti untuk mengungkap perbedaan respons perubahan TIO setelah melakukan senam aerobik dengan perbedaan beban olahraga yaitu intensitas sedang dan tinggi.

\section{HIPOTESIS}

1. TIO sesudah senam aerobik intensitas sedang lebih kecil dibandingkan dengan TIO sebelum senam.

2. TIO sesudah senam aerobik intensitas tinggi lebih kecil dibandingkan dengan TIO sebelum senam.

3. TIO sesudah senam aerobik intensitas tinggi lebih rendah dibandingkan dengan TIO sesudah senam aerobik intensitas sedang.

\section{TEKANAN INTRAOKULER}

Tekanan intraokuler berfungsi mempertahankan bola mata dalam suatu bentuk tertentu, sehingga mata dapat berfungsi sebagai alat optik. Menurut beberapa penelitian, TIO pada manusia bervariasi. Hoskin $(1999)^{4}$ mendapatkan TIO 15,8-20,6 mmHg, Stamper $(1988)^{6} \quad 10,5-20,5 \mathrm{mmHg}$, dan Shield (1997) ${ }^{7}$ 10-20 mmHg. Moses (1987) ${ }^{8}$ mendapatkan TIO rata-rata manusia normal yang diukur pada posisi duduk dengan menggunakan tonometer Schiotz yaitu 15,4 mmHg. Penelitian Ferndale (1996) pada lebih dari 4000 individu mendapatkan TIO penderita glaukoma $\geq 20 \mathrm{mmHg}$, yang serupa dengan Dalby (1981) yaitu >20,5 mmHg. ${ }^{4,8,9}$

TIO dipengaruhi oleh faktor pembentukan cairan akueus, daya pengeluaran cairan akueus dari dalam mata, dan tekanan dalam vena episklera. Pembentukan cairan akueus terutama ditentukan oleh transportasi ion-ion secara aktif serta bahan pembentuk cairan akueus yang terpenting yaitu bikarbonat. Pembentukan cairan akueus selain oleh transportasi ion-ion secara aktif, juga melalui ultrafiltrasi cairan dari kapiler ke dalam mata, yang dipengaruhi tekanan hidrostatik dan difusi.

Pembentukan cairan akueus juga dipengaruhi oleh umur. Brubaker et al $(1981)^{10}$ meneliti 300 sukarelawan dewasa normal dan mendapatkan penurunan pembentukan cairan akueus setiap dekade sebesar 2,5\%, sedangkan pembentukan cairan akueus pada pria dan wanita tidak berbeda bermakna. Penelitian lain menyatakan bahwa TIO wanita lebih tinggi dibandingkan pria, terutama setelah usia 40 tahun; hal ini menunjukan adanya hubungan antara TIO dengan usia. $^{9}$

Proses pembentukan bikarbonat sebagai bahan dasar cairan akueus terpenting dipengaruhi oleh tiga faktor: enzim karbonik anhidrase, karbondioksida, dan air. Pada latihan dengan metabolisme yang bersifat anaerob terjadi penumpukan asam laktat. Efek ini menyebabkan $\mathrm{pH}$ darah 
menurun sehingga terjadi asidosis sistemik. Usaha tubuh untuk menaikkan $\mathrm{pH}$ darah kembali normal dilakukan dengan cara bikarbonat sebagai buffer mengikat hidrogen membentuk asam karbonat. Dengan demikian, ion bikarbonat untuk sintesis cairan akueus akan berkurang sebanyak $40 \%$. Bila pembentukan serta daya pengeluaran cairan akueus berkurang maka TIO akan menurun. ${ }^{7,10}$

Senam aerobik merupakan salah satu olahraga yang dapat meningkatkan dan memelihara kapasitas aerobik; gerakannya dapat dibuat menjangkau seluruh persendian dan otot. Dosis dimulai dari yang paling ringan, khususnya untuk pelemasan serta perluasan pergerakan persendian, sampai pada bentuk-bentuk gerakan untuk meningkatkan kekuatan daya tahan otot. Seseorang yang mampu melakukan senam aerobik berarti kapasitas aerobik, kekuatan otot, daya tahan otot, luas pergerakan persendian, kesemuanya ini dapat ditingkatkan.

Menurut Fox (1988) ${ }^{11}$ intensitas latihan dapat diketahui dari frekuensi denyut nadi permenit. Pengukuran denyut nadi menurut McArdle et al (2001) ${ }^{12}$ serta Giam and Teh (1993), ${ }^{13}$ yaitu dengan menggunakan rumus 220-usia. Pollock dan Wilmore (1988) mengklasifikasikan intensitas latihan berdasarkan pencapaian frekuensi denyut jantung maksimal (DJM) yaitu: $<35 \%$ DJM: sangat ringan; 35-59\% DJM: ringan; 60-79\% DJM: sedang; 80-89\%: tinggi; $\geq 90 \%$ DJM: sangat tinggi. ${ }^{11-13}$

\section{METODOLOGI PENELITIAN}

Penelitian ini merupakan penelitian eksperimental lapangan dengan rancangan one group pretest-post test design. Penelitian dilaksanakan di sanggar senam Felisia, Manado.

Populasi mencakup semua anggota sanggar senam Felisia, Manado, yang berjumlah 65 orang. Sampel yaitu semua responden penelitian anggota sanggar senam Felisia Manado yang memenuhi kriteria inklusi yakni sebanyak 30 orang yang berusia 20-40 tahun, tidak mempunyai gangguan neuromuskular, baru pertama kali mengikuti senam aerobik, serta bersedia menandatangani informed concent.

\section{HASIL PENELITIAN}

\section{Karakteristik subyek}

Subyek penelitian sejumlah 30 orang anggota sanggar senam Felisia Tikala Baru Manado, berusia 20-40 tahun, sehat, status gizi baik (Indeks Massa Tubuh/IMT normal), tidak mempunyai gangguan mata, baru pertama kali mengikuti kegiatan senam aerobik, serta tidak melakukan aktivitas olahraga lainnya. Subyek melakukan kegiatan senam aerobik intensitas sedang dan intensitas tinggi.

\section{Denyut nadi}

Hasil analisis statistik menunjukkan bahwa nilai rata-rata denyut nadi latihan inti pada senam aerobik intensitas sedang (menit ke-5 sampai ke-25) 122,48 $\pm 2,89$ kali per menit (Gambar 1), dan untuk nilai rata-rata denyut nadi latihan inti pada senam aerobik intensitas tinggi (menit ke-6 sampai ke-15) $152,06 \pm 3$ kali per menit (Gambar 2)

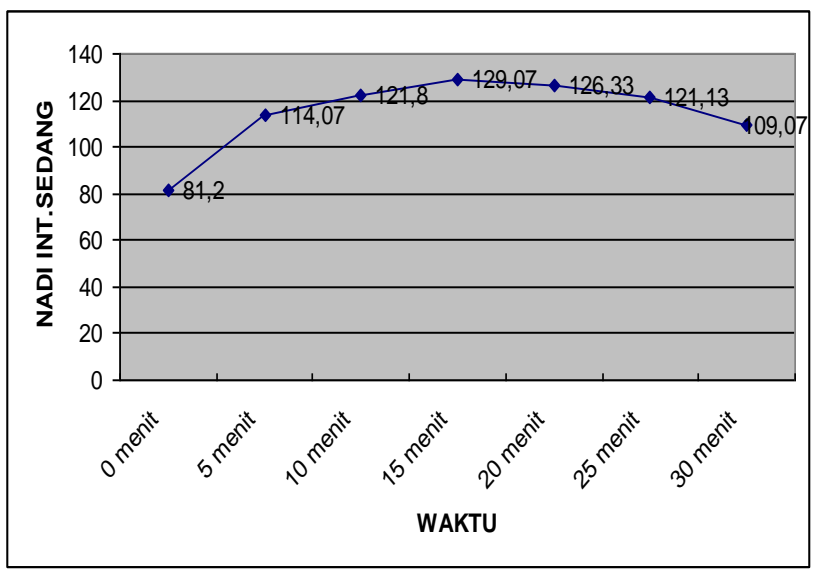

Gambar 1. Karakteristik denyut nadi kelompok perlakuan senam aerobik intensitas sedang $(\mathrm{N}=30)($ rerata $\pm \mathrm{SD})$. 


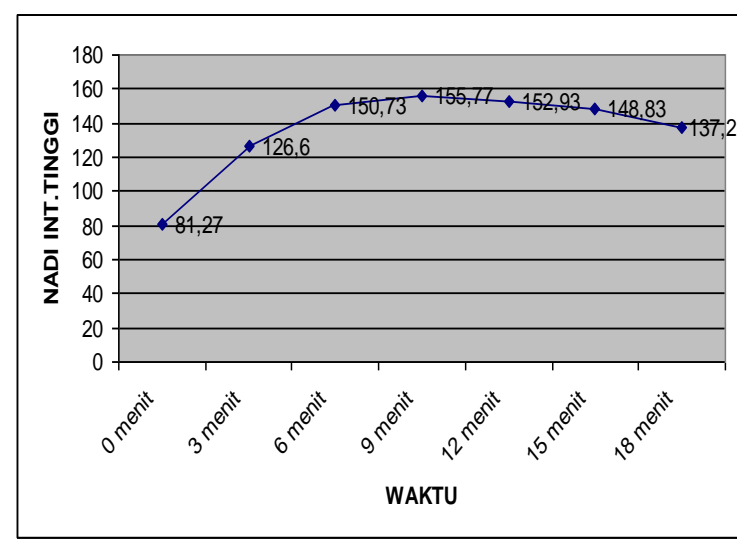

Gambar 2. Karakteristik denyut nadi kelompok perlakuan senam aerobik intensitas tinggi $(\mathrm{N}=30)($ rerata $\pm \mathrm{SD})$.

\section{Tekanan darah}

Dari hasil uji statistik diperoleh bahwa tekanan darah sistolik dan diastolik pada kelompok sebelum $(P=0,677 ; P>0,05)$ dan sesudah senam aerobik intensitas sedang $(P=0,536 ; P>0,05)$, tidak menunjukkan pengaruh yang nyata (Gambar 3 ).

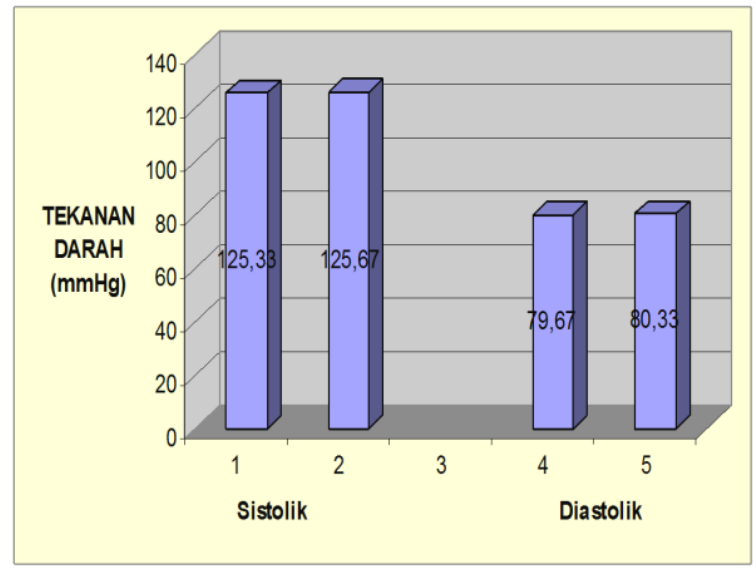

Gambar 3. Karakteristik tekanan darah sistolik dan diastolik sebelum dan sesudah senam aerobik intensitas sedang $(\mathrm{N}=30)($ rerata $\pm \mathrm{SD})$.

Dari hasil uji statistik diperoleh bahwa tekanan darah sistolik dan diastolik pada kelompok sebelum $(P=0,769 ; P>0,05)$; dan sesudah senam aerobik intensitas tinggi $(P=0,879 ; P>0,05)$, tidak menunjukkan pengaruh yang nyata (Gambar 4).

Nilai tekanan darah sistolik dan diastolik sesudah senam aerobik intensitas

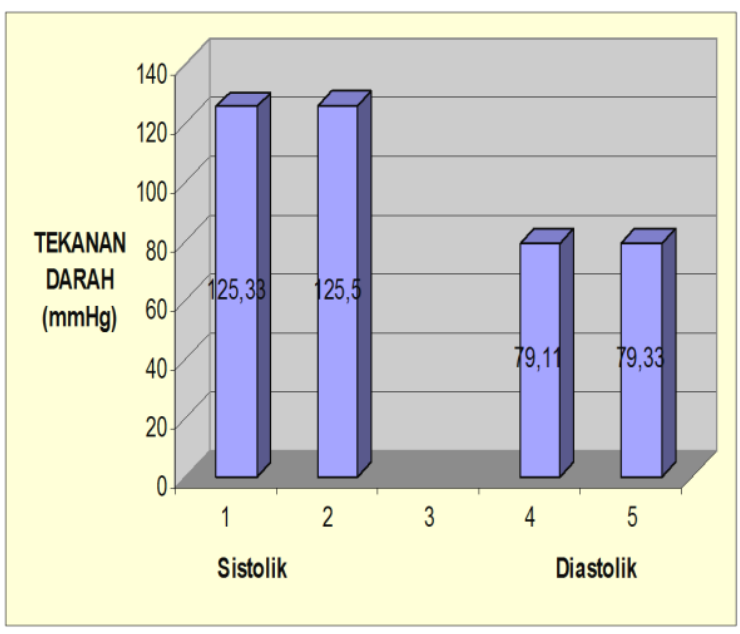

Gambar 4. Karakteristik tekanan darah sistolik dan diastolik sebelum dan sesudah senam aerobik intensitas tinggi $(\mathrm{N}=30)($ rerata $\pm \mathrm{SD})$.

sedang dan tinggi diambil pada fase pemulihan (30 menit sesudah senam).

\section{Tekanan intraokuler}

Perbandingan nilai rata-rata TIO pada kelompok perlakuan sebelum dan sesudah melakukan latihan senam aerobik intensitas sedang yakni $16,74 \pm 1,385 \mathrm{mmHg}$ vs $15,37 \pm 1,261 \mathrm{mmHg}$, sedangkan pada kelompok intensitas tinggi perbandingan nilai rata-rata TIO yakni $16,74 \pm 1,385$ mmHg vs 12,91 $\pm 1,111$ mmHg (Gambar 5).

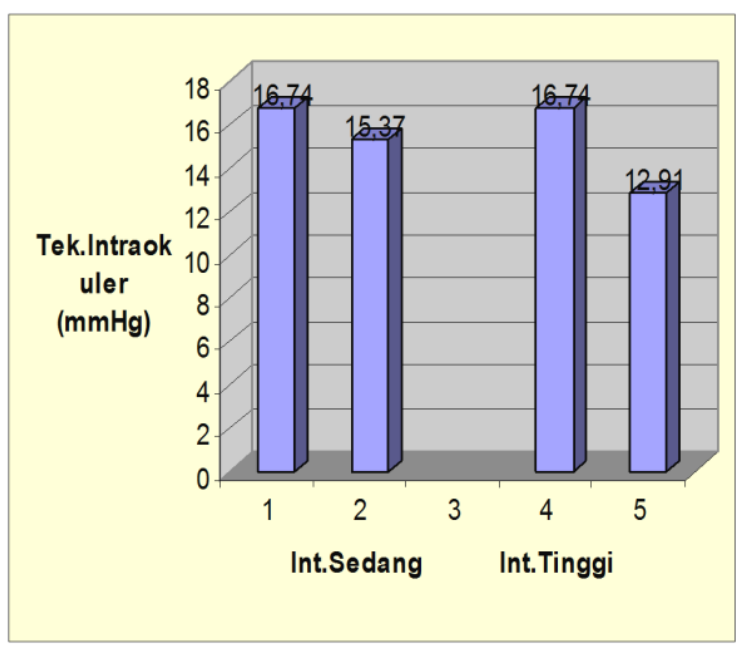

Gambar 5. Nilai TIO kelompok perlakuan sesudah senam aerobik intensitas sedang dan kelompok intensitas tinggi dengan jumlah sampel 30 (rerata \pm SD). 
Hasil analisis statistik menunjukkan nilai TIO sesudah senam aerobik pada kelompok perlakuan dengan intensitas sedang menurun secara bermakna $(P<0,05)$ dibandingkan dengan nilai TIO sebelum latihan senam aerobik intensitas sedang.

Nilai TIO sesudah senam aerobik pada kelompok perlakuan dengan intensitas tinggi menurun secara sangat bermakna $(P$ $<0,05)$ dibandingkan dengan nilai TIO sebelum latihan senam aerobik intensitas tinggi.

Nilai TIO sesudah senam aerobik pada kelompok perlakuan dengan intensitas tinggi menurun secara sangat bermakna $(P<0,05)$ dibandingkan dengan nilai TIO sesudah latihan senam aerobik intensitas sedang.

\section{BAHASAN}

\section{Karakteristik subyek}

Data penelitian menunjukkan rerata umur 34,20 $\pm 4,817$ tahun. Pada proses perkembangan mata sebagai alat penglihatan yang normal terdapat fase plateau antara usia 20-40 tahun dimana terjadi perkembangan sesuai dengan pertumbuhan badan sampai usia 20 tahun dan menurun setelah usia 40 tahun. $^{14}$

Rerata berat badan yaitu $53,26 \pm 3,483$ $\mathrm{kg}$ dan rerata tinggi badan yaitu 154,52 \pm $3,115 \mathrm{~cm}$. Data menunjukkan bahwa subyek mempunyai karakteristik fisik dalam batas normal.

Besarnya rerata IMT yaitu $22,32 \pm 1,368$ $\mathrm{kg} / \mathrm{m}^{2}$, menunjukkan bahwa subyek berada dalam kategori status gizi yang baik sesuai dengan rumus IMT $=\mathrm{BB}(\mathrm{kg}) / \mathrm{TB}(\mathrm{m})^{2}$. Giam dan Teh (1993) menyatakan bahwa individu dengan status gizi yang baik dapat mencapai kesegaran jasmani yang optimum, sehingga mampu bertahan pada latihan dengan intensits tinggi. 13

\section{Pengaruh senam aerobik terhadap denyut nadi}

Denyut nadi latihan dihitung pada saat latihan inti. Menurut Mc.Ardle et al (2001) serta Giam dan Teh (1993), penghitungan dilakukan dengan menggunakan rumus: 220 - usia. $^{11-13}$

Rerata usia pada kelompok intensitas sedang 34,37 $\pm 4,374$ tahun. Hal ini berarti nadi untuk kategori intensitas sedang yang harus dicapai sebesar (220-34) $\times(60-79)=$ 111-147 x/menit. Hasil denyut nadi yang dicapai selama latihan inti $122,48 \pm 2,89$ $\mathrm{x} /$ menit menunjukkan bahwa intensitas denyut nadi yang dicapai memenuhi kriteria untuk kategori intensitas sedang (60-79\% DNM) menurut Polloc dan Wilmore (1988). ${ }^{14}$ Giam dan Teh (1993) ${ }^{13}$ mengemukakan bahwa latihan berkisar 15-30 menit dinilai sudah cukup didahului dengan 3-5 menit pemanasan dan diakhiri dengan 3-5 menit pendinginan. Lamanya latihan sangat berkaitan dengan intensitas latihan sehingga latihan aerobik dapat dilakukan dengan program longduration-low intensity atau short durationhigh intensity, selama zona latihan terpenuhi yaitu $60-90 \%$ DJM. ${ }^{8,13,14}$

Rerata usia pada kelompok intensitas tinggi 34,40 \pm 4,359 tahun. Hal ini berarti nadi untuk kategori intensitas tinggi yang harus dicapai sebesar (220-34) x (80-89) $=149-165$ kali per menit. Hasil denyut nadi yang dicapai sebesar 152,06 $\pm 3,201 \mathrm{x} /$ menit menunjukkan bahwa intensitas denyut nadi yang dicapai memenuhi kriteria nadi intensitas tinggi (8089\% DNM) menurut Polloc dan Wilmore (1988). ${ }^{14}$

Peningkatan denyut nadi pada senam aerobik intensitas tinggi lebih besar dibandingkan yang intensitas sedang. Hal ini disebabkan irama/tempo lagu yang lebih cepat serta adanya variasi gerakan berupa kombinasi high impact (meliputi gerakan berputar dengan kedua kaki diangkat tinggi ke udara pada saat bersamaan) dan low impact (gerakan berdampak rendah dengan mewajibkan paling tidak satu kaki tetap berada di lantai selama latihan). ${ }^{11,12,15}$

Secara teoritis peningkatan denyut jantung ini akan mempengaruhi beberapa fungsi fisiologik tubuh, termasuk pengaturan suhu tubuh dan metabolisme bahan-bahan kimia dalam tubuh.

Curah jantung selama latihan akan meningkatkan aliran darah secara proporsional dengan meningkatnya intensitas latihan. Pada latihan taraf 40-60\% dari kapasitas maksimal, 
curah jantung bisa mencapai 30-40 liter per menit, sedangkan orang yang tidak terlatih memiliki kemampuan kerja dan curah jantung maksimal lebih rendah yaitu sekitar 20-25 liter per menit. ${ }^{16}$ Penelitian Stone dan O'bryant (1987) menunjukkan bahwa sesaat setelah melakukan latihan fisik terterjadi peningkatan denyut jantung; hal ini tergantung pada beban serta besarnya kelompok otot yang bekerja. Bila pada otot jantung regangannya bertambah, misalnya terdapat jumlah darah tambahan masuk ke ruang-ruang jantung, regangan otot yang tidak biasa terjadi ini menyebabkan otot jantung berkontraksi dengan kuat, sehingga secara otomatis memompa darah tambahan ke dalam arteri-arteri. ${ }^{17,18}$

\section{Pengaruh senam aerobik terhadap tekan- an darah sistolik dan diastolik}

Sebelum aktivitas fisik dimulai, pikiran akan merangsang sistem saraf otonom, yang meningkatkan frekuensi dan kekuatan kontraksi jantung. Jadi, terjadi peningkatan pompa jantung dari tingkat normal 13-15 liter per menit menjadi 20-25 liter per menit (atau sampai 35 liter per menit pada atlit terlatih). Secara bersamaan, rangsangan simpatis menyempitkan vena-vena di seluruh tubuh, yang dapat meningkatkan tekanan pengisian sistemik sampai setinggi dua setengah kali normal, jadi mendorong sejumlah darah tambahan dari sirkulasi perifer ke jantung. Kedua efek ini meningkatkan curah jantung dengan segera sebesar 50\%, bahkan sebelum aktivitas fisik dimulai. ${ }^{18}$

Pada permulaan aktivitas fisik, korteks motorik mengirimkan sinyal langsung ke sistem saraf simpatis untuk lebih memperkuat derajat kegiatan simpatis, serta meningkatkan aktivitas jantung, tekanan sistemik rata-rata, dan tekanan arteri. ${ }^{19}$

Dalam batas-batas fisiologik peregangan otot jantung akan meningkatkan daya kontraksinya, tetapi bila tekanan arteri meningkat di atas $170 \mathrm{mmHg}$, beban tekanan arteri akan menyebabkan jantung mulai payah. ${ }^{18}$ Tekanan darah diastolik terutama ditentukan oleh curah jantung dan resistensi vaskuler. Selama latihan, curah jantung meningkat dan resistensi vaskuler sekitarnya menurun sebagai respon terhadap vasodilatasi dan resistensi pembuluh dalam otot-otot rangka. Peningkatan tekanan darah diastolik selama latihan dapat diakibatkan oleh curah jantung yang tinggi atau lemahnya vasodilatasi dari resistensi pembuluh darah pada otot-otot rangka.

\section{Pengaruh senam aerobik terhadap TIO}

Hasil analisis statistik memperlihatkan bahwa nilai TIO sesudah senam aerobik intensitas sedang menurun secara bermakna $(P<0,05)$ dibandingkan nilai TIO sebelum senam aerobik. Hal ini terlihat pada hasil rerata TIO pada kelompok perlakuan sebelum senam aerobik intensitas sedang sebesar 16,74 $\pm 1,385 \mathrm{mmHg}$ dan sesudah senam menurun menjadi $15,37 \pm 1,261$ $\mathrm{mmHg}$. Hasil ini menunjukkan aktivitas senam aerobik intensitas sedang dapat menurunkan nilai TIO secara bermakna dibanding dengan tanpa (sebelum) senam aerobik.

Nilai TIO sesudah senam aerobik intensitas tinggi menurun secara bermakna $(P<0,05)$ dibandingkan nilai TIO sebelum senam aerobik. Hal ini terlihat pada hasil rerata TIO pada kelompok perlakuan sebelum senam aerobik intensitas tinggi sebesar $16,74 \pm 1,385 \mathrm{mmHg}$ dan sesudah senam menurun menjadi $12,91 \pm 1,111$ mmHg. Hasil ini menunjukkan aktivitas senam aerobik intensitas tinggi dapat menurunkan nilai TIO secara bermakna dibanding dengan tanpa (sebelum) senam aerobik.

Terdapat perbedaan nilai yang bermakna $(P<0,05)$ untuk nilai TIO antara sesudah senam aerobik intensitas sedang dan sesudah senam aerobik intensitas tinggi. Hal ini terlihat pada hasil rerata TIO pada kelompok perlakuan sesudah senam aerobik intensitas sedang sebesar 15,37 \pm $1,261 \mathrm{mmHg}$ dan sesudah senam aerobik intensitas tinggi menurun menjadi 12,92 \pm 1,111. Dalam hal ini, TIO sesudah senam aerobik intensitas tinggi mempunyai nilai yang lebih rendah dibanding TIO sesudah senam aerobik intensitas sedang.

Hasil penelitian ini didukung oleh 
penelitian Qureshi (1995) ${ }^{19}$ yang mendapatkan perbedaan dalam hal penurunan TIO pada orang dewasa non atlit setelah melakukan aktivitas duduk, jogging, dan lari cepat. Penurunan TIO ini disebabkan oleh penumpukan asam laktat yang menyebabkan $\mathrm{pH}$ darah menurun sehingga terjadi asidosis sistemik. Keadaan ini menyebabkan tubuh secara fisiologik berusaha untuk menaikkan $\mathrm{pH}$ darah kembali normal yaitu dengan cara bikarbonat sebagai buffer mengikat hidrogen membentuk asam karbonat. Dengan demikian ion bikarbonat untuk pembentukan cairan akueus akan berkurang sebanyak $40 \% .^{6}$ Bila pembentukan dan daya pengeluaran cairan akueus berkurang maka TIO akan mengalami penurunan. Junaidi (1999) ${ }^{5}$ meneliti pengaruh latihan beban terhadap TIO dengan melakukan kontraksi isometrik menggunakan alat dinamometer dorong pada orang normal. Hasil penelitian menunjukkan bahwa setelah 30 menit didapatkan tekanan intraokuler menurun sebesar 3 mmHg. ${ }^{5}$ Karabtakis et al (2004) meneliti olahraga jogging mendapatkan penurunan TIO pada kedua bola mata pada sebagian besar orang coba. $^{21}$

\section{SIMPULAN}

Berdasarkan hasil penelitian dan pembahasan dapat disimpulkan bahwa senam aerobik intensitas sedang dan tinggi dapat menurunkan tekanan intra-okuler. Selain itu, nilai tekanan intraokuler sesudah latihan senam aerobik intensitas tinggi lebih rendah dibandingkan sesudah senam dengan intensitas sedang.

\section{DAFTAR PUSTAKA}

1. Chandler PA, Grant WM. Lectures on glaukoma. Philadelphia: Lea and Febinger, 1965; p.136.

2. Departemen Kesehatan RI. Survey Kesehatan Indera Penglihatan 1993-1996. Jakarta: Departemen Kesehatan, 1997; 22-23.

3. Hall JE. Fluid system of the eye - intra ocular fluid. In: Guyton AC, Hall JE, editors. Review of Medical Physiology (Ninth Edition). Philadelphia: WB Saunders, 1996; p. 642-55.

4. Hoskins HD, Kass MA. Primary open angle glaucoma In: Diagnosis and Therapy of Glaucomas (Seventh Edition). St. Louis: CV Mosby, 1999; p. 277-81.

5. Junaidi. Pengaruh latihan isometrik terhadap tekanan intra okular (Tesis). Jakarta: Ilmu Kedokteran Olah Raga FKUI; 1999.

6. Shield MB. Textbook of Glaucoma. Baltimore: Williams \& Wilkins, 1987.

7. Moses AR. Adler's Physiology of the Eye Clinical Application (Eight Edition). St. Louis: CV Mosby, 1987; p.234-40.

8. Kiuchi Y, Mishiam HK, Hotema Y, Furomoto A, Hirota A, Onri IC. Exercise intensity determines the magnitude of IOP decrease after running. Japan $\mathrm{J}$ Ophthalmol. 1999;38:191-5.

9. Brubaker RF. The effect of age on aqueous humor formation in man. Ophthalmology, 1981; p. 283-4.

10. Stamper RL. Biomedical Foundation of Ophthalmology. Philadelphia: Harper \& Row Publisher, 1988.

11. Fox EL, Bowers RW, Foss ML. The Physiological Basis of Physical Education and Athletics (Fourth Edition). Philadelphia: Saunders College Publishing, 1988.

12. Mc Ardle WD, Kacth FI, Katch VL. Exercise Physiology (Fourth Edition). Baltimore: Williams \& Wilkins, 1996.

13. Giam CH, Teh CK. Ilmu Kedokteran Olahraga (Satmoko H, penerjemah). Jakarta: Binarupa Aksara, 1993.

14. Higgins MW, Enright PL, Kronmal RA. Smoking and lung function in elderly men and women. JAMA. 1993;9:17-25.

15. Pollock ML, Willmore JH. Exercice prescription for elderly. In: Eckert HM, editor. Human Kinetics Books. Kansas: The American Academy of Physical Education, 1988.

16. Davidson WT, Atchinson JW, Grants SA. A Comparison of Physiological Responses and Rate of Perceived Exertion A High Impact and Low Impact Aerobic Dance in Bases. 1996; p.176-177.

17. Walter DG, Mosby S. Dictionary Medical, Nursing \& Allied Health (Third dition). 
St. Louis: CV Mosby, 1990; p.447-448.

18. Passo MS, Goldberg L, Elliot DL, Van

Busrik EM. Exercise conditioning and intraocular pressure. Am J Ophthalmol. 1987; 103:734-757.

19. Guyton AC, Hall JE. Textbook of Medical
Physiology (Eleventh Edition). Philadelphia: WB Saunders, 2007.

20. Qureshi IA. Effect of exercise on intraocular pressure in physically fit subject. Clin Exp Pharmacol Physiol. 1996;23:648-52. 